\title{
Correlation between Election and Examination Malpractices as Perceived by Adults in Delta State
}

\author{
G. G. Ogbebor, Ph.D.
}

Delta State University, Abraka

Ogbebor Uruemu

University Of Ibadan, Ibadan- Nigeria

\author{
Doi:10.5901/jesr.2015.v5n3p209
}

\begin{abstract}
The research investigated the Electoral Malpractice as a deviant behaviour among adults in Delta State, Nigeria. The researcher related this deviant behaviour to examination malpractice in the University. The focus was to find out whether election malpractice in the outer society has affected the morality of our youths as seen in the involvement of students in examination malpractice, another deviant behaviour among Nigeria youths in our Universities. The purpose was to find out whether election malpractice has some influence on examination malpractice. It was an inferential study that used the survey design, guided by three research questions and one hypothesis. Data was collected using questionnaire. The population was about 2.5 million adults, and the sample used was 500 male and female. The data collected was analysed with percentage frequency and correlation method of data analysis. The result showed that when malpractice is exhibited during elections, it could affect the moral development of the growing youths and also encourage examination malpractice. The researcher recommended that elections should be conducted in a free and fair situation; there should be citizenship education where free and fair elections is emphasised, with emphasis also on non-participation of students in examination malpractice.
\end{abstract}

Keywords: Deviant Behaviour, Electoral Malpractice, Examination Malpractice.

\section{Introduction}

The delinquent behaviour found among Nigeria Adults is that of cheating during elections to different segments of governance. These are elections to the national, states and local government legislative houses and the position of the nation's presidency, governorship and local government chairmanship seats.

This electoral adulthood delinquent behaviour has a similar delinquent behaviour among the younger generation in institutions of learning. This is the infamous examination malpractice found among students.

The problem the researcher has observed is the relationship that exists between these two deviant behaviours found among the adults and the younger generation in Nigeria today. The researcher sought to know whether the cheating that is found during electoral activities is being copied by the students in the University. The study also wanted to see if this adulthood malpractice at elections has relationship with students' examination malpractice in the University, and to study the imitational correlation of electoral malpractice among adults and students and whether this adult delinquency has effects on the development of morality on the younger generation.

In Nigeria today, adults take pride in rigging elections, and the youths watch them. In some cases, these youths in the Universities are involved in the cheating process. This cheating in elections is seen to be similar to election in campuses. Campus elections into students' executive positions as members of Students Union Government are marred with malpractices. Students' elections are no more free and fair. It is now a matter of survival of the fittest. This situation is seen during examinations so that students take pride in cheating during examinations. They leave the examination hall priding themselves that they have successfully cheated. This is the general scenario between elections in the society, students' elections into Student Union Governance and malpractices at University examinations. In the distant past, outside elections, Student Union elections and examinations were free and fair. In such distant days in Nigeria, there was normalcy in these three spheres of societal life. Then, elections and examinations in schools and universities were conducted with transparency. Today, things have taken different shapes. The researcher wanted to see whether malpractices during elections have relationship on the moral behaviour of our youths at the university level, and whether 
this deviant adult behaviour have relationship with students' actions so that they are encouraged to become involved in examination malpractices. The purpose was to find out whether there is a relationship between election malpractice and examination malpractice as adult deviant behaviour in the Nigerian society.

\section{Literature Review}

The literature review related to this study discussed what deviant behaviour is, causes of deviant behaviour, effects of deviant behaviour, and solutions to deviant behaviour. It also reviewed election malpractices in Nigeria, and the extent of examination malpractices in the universities.

\section{Meaning of Deviance}

Morgan, King, Weisz and Schopler (2008) say that an individual's behaviour is expected to conform with that of an intact group; if this is not so, then the person is seen to have a deviant behaviour. However, this behaviour is expected to change to the accepted one by the group, says Morgan et al. Chirasha (2010) states that when behaviour has developed or deteriorated so that the individual's action becomes a problem to others, then it is said to be a deviant behaviour. Behaviour is deviant when there is a voluntary action that violates institutionalised norms and threatens wellbeing. From the above, one can say that behaviour is deviant if it is not in accordance with community standards. For behaviour to be deemed deviant, it must deviate from some accepted norm. We can see that deviant behaviour is a behaviour which does not adhere to widely accepted social or cultural norms. Bolin and Heathery (2001) state in addition, that deviant behaviour can be constructive or destructive.

\subsection{Theories of Deviant Behaviour}

Borg and Gall (1989) reported two theories of deviant behaviour. These include law enforcement theory and criminal justice theory. According to them, the law enforcement theory emanate from legislation and enforcement of such legislative acts while the criminal justice theory is the interpretation of the legislative acts that have arisen from reports of the law enforcement agents.

\subsection{Causes of Deviant Behaviour}

Deviant behaviour according to Brown (1999) may be caused by such factors as biological factors, maladjustment and psychosocial factors. The two factors according to Brown are interpersonal causes, organisational justice causes, work place environment, and perceived organisational support. Others according to the author include trust in organisation causes, work stress causes, and powerlessness causes.

\subsection{Effects of Deviant Behaviour}

Different effects of deviant behaviour have been recognised. These were explained by Chirasha and Mahapa (2010) to include deviant behaviour impacts that are negative, on both the organisation and total output. There are those with moral impacts, and motivational impact. In addition, the authors state that deviant behaviour can have financial impact on industries. They also stated that deviant behaviour can cause fraud cases, employee theft and even violence; and that in many situations, it can cause shoplifting in commercial establishments.

\subsection{Treatment and Solutions for Deviance}

According to Morgan et al. (2002), deviant behaviour can be changed or treated through the process of conformity. They stated that group pressures are particularly in situations that necessitate a change to acceptable behaviour and that deviant behaviour can be corrected by group pressure. They also stated that deviant behaviour are controlled by enactment of rules; that groups cannot exist without rules that regulate members' behaviour and that rules serve to coordinate behaviour, to avoid conflict between members. Thibant and Kelley (1959) state that laws are made by legislators to treat and find solution for deviance, and these are enforced by the police. They added that punishment ranged from mild to severe ones to control and minimise deviant behaviour. Burton, Michel and Lee (2005) 
recommended that feedback from peers, community forums, heart to heart chats, and sympathetic system administration can also help in the treatment of deviance and that psychoanalytic approach such as attention seeking solution can also help.

\subsection{Election Malpractices}

Election malpractice is when election results are altered in favour of a particular candidate or party. It is when candidates use illegal means to ensure that he gets a favourable result. Under normal situations, politics should not be a situation where malpractice occurs. The word politics comes from the Greek word "politicos" modelled on Aristotle's view of affairs of the state (Liddel\& Scott, 2008). Today, people are deeply engaged in violent clashes and malpractices in politics. This occurs in the larger society and in tertiary institutions. The focus of this research is influenced by this situation, to find out whether political malpractice in the larger society and in tertiary institutions has correlation influence on examination malpractice in the universities.

It is often assumed that political malpractice only occurs at the level of politics for government position. This is not so, it also occurs at the university levels. One wonders if this virus that has penetrated the universities has not also influenced the moral attitude of students in relation to their examination behaviour (Lewis, 2008). Liddel \& Sciott (2008) say that politics occurs where people disagree about the distribution of resources and have at least procedures for the resolution of such disagreement. They added that this should not bring about election malpractice. It is not politics in the state of nature where people engage in malpractice.

\subsection{Examination Malpractices}

Ogba (2004) defined examination malpractice as a situation where extra-ordinary means are employed to make students have advantage over others. Usually these extra-ordinary means are used against the rules of the examining body. Here in Nigeria, Ogba says, students, parents, teachers and even examiners are involved. He added that this situation can have far reaching negative effects on the moral development of the young people in the society and the country at large. He went further to state that the hydraheaded problem of examination malpractice is presently growing at an alarming rate and posing a serious threat to the Nigeria entire educational system. The researcher states that examination malpractice is destroying the Nigeria educational standard and image. Taiwo (2004) expressed concern and worry over the collaboration of invigilators, supervisors, lecturers and some syndicates, parents, guidance and officials entrusted with the responsibility of conducting examinations. It is these same adults in the society that are involved in political elections that are involved in examination malpractices in tertiary institutions. This is why this researcher is interested in finding out whether political malpractices in the wider society have a relationship or is capable of influencing examination malpractices in our Universities. This is the focal point of this study.

\section{Research Problem}

The researcher has observed some similarities between election malpractices in the Nigerian society and the tertiary institutions with examination malpractices. The similarities include morality absence, the influence of super-ego, and absence of regard for national image. Others include self-centeredness and disregard for the values of the society. The researcher investigated evidence of election malpractices, the opinion of respondents on election malpractice and what their conscience are on the act. The researcher also wanted to find out if these deviant behaviours have effects on the growing youths in the universities; and the influence election malpractice has on the attitude of students to examination malpractices.

\subsection{Research Questions}

Three research questions and one hypothesis were stated to guide the study.

1) Are there evidences of election malpractice during elections in Delta State?

2) If a political party is powerful enough, should the party use this power to rig election?

3) When election malpractice occurs in the society, can this have effects on students' attitude towards examination conducted in their schools? 


\subsection{Research Hypothesis}

$\mathrm{Ho}_{1}$ : There is no significant relationship between election malpractice and examination malpractice in the Nigerian society.

\subsection{Research Method}

\subsubsection{Participants}

\subsubsection{Population, Sample and Sampling Techniques}

The population for this study was drawn from the 3 Senatorial Districts that make up Delta State. These were: Delta North, Delta Central and Delta South. The 1996 census shows that the entire Delta State population is about 2.5 million adults including male and female. The sample was five hundred (500) adults both male and female. The researcher got respondents from 3 Local Government Areas, one from each Senatorial district. The Local Government Areas were: Ika South (166), Ethiope East (168) and Isoko South (166) respondents. This is a cluster method of sampling and every cluster was selected through random sampling using balloting system.

\subsubsection{Instrumentation}

The instrument used for this study was the questionnaire titled "Election Malpractice Related to Examination Malpractice". The items in the questionnaire were related to the research problem and the research questions and hypothesis that guided the study. Since the main variables were election malpractices and examination malpractices, the items in the research questionnaire were drawn around these variables. The questionnaire was made up of 10 items. The responses were got through the use of choice of 'yes' and 'no' alternatives that were indications of the relevant variables.

To ensure validity of the items, the instrument used represented the content of interest, that is, all the main variables. These include electoral malpractice and examination malpractice. The scoring method was quite objective. It was simply a choice between 'yes' and 'no' to the items in the questionnaire. Each item in the questionnaire was related to the study variables. The questionnaire had earlier been administered on a separate sample to ensure reliability. The researcher ensured the reliability of the instrument using test-retest method, which was analysed with Pearson Product Moment Correlation Co-efficient Statistics. The correlation established was 0.89 . It was after the reliability had been established that the questionnaire was administered to the study sample of 500 respondents.

\subsubsection{Design}

The study was a descriptive study, which used a correlational design. The study focused on whether the practice where election is rigged have relationship with examination malpractices in our universities.

\subsubsection{Statistical Model}

The percentage method of data analysis was adopted to find answers to the 3 research questions, while the research hypothesis was analysed using the Pearson Product Moment Correlation Co-efficient. These two statistical methods were adequate since the response patterns were the 'yes' and 'no' both for the research questions and the hypothesis. To establish the percentage of the responses, the researcher calculated the responses for the two (yes, no) and established the frequencies.

\subsubsection{Result}

The result of this research revealed that elections held in Delta State has evidence of malpractice in its conduct; that no matter how powerful any political party is, that party should not be involved in malpractice, that election should be free and fair and that rigging should not be part of election process.

The result also revealed that when malpractice is exhibited during elections, it could affect the moral development 
of the growing youths and the growing population, also that there is a significant relationship between election malpractice and examination malpractice in universities and both are evidence of adult deviant behaviour.

\subsection{Research Questions}

\subsubsection{Research Question I}

Are there evidences of election malpractice during elections in Delta State?

Table 1: Patterns of Distribution of Evidence of Election Malpractice

\begin{tabular}{cccc}
\hline Total Items & Response & Frequency & Percent \\
\hline \multirow{3}{*}{10} & Yes & 406 & 81.2 \\
& No & 94 & 18.8 \\
& Total & $\mathbf{5 0 0}$ & 100 \\
\hline
\end{tabular}

From table 1, it reveals that 406 respondents representing 81.2 percent of the total respondents agreed that there is evidence of election malpractice in Delta State. While 94 respondents representing 18.8 percent of the total respondents disagree that there are evidences of election malpractice. The implication of this finding is that elections held in Delta State has evidence of malpractice in its conduct (See Appendix 1).

\subsubsection{Research Question 2}

If a political party is powerful enough, should the party use this power to rig election?

Table 2: Patterns of Distribution showing whether powerful party in Delta State should use their power to rig election

\begin{tabular}{cccc}
\hline Total Items & Response & Frequency & Percent \\
\hline \multirow{3}{*}{10} & Yes & 206 & 41.2 \\
& No & 294 & 58.8 \\
\cline { 2 - 4 } & Total & $\mathbf{5 0 0}$ & $\mathbf{1 0 0}$ \\
\cline { 2 - 4 } & & &
\end{tabular}

The result of analysis showed that 206 respondents representing 41.2 percent of the total respondents to the questionnaire agreed that powerful party in Delta State should use their power to rig election in Delta State; while 294 respondents representing 58.8 percent of the total respondents disagreed that powerful party in Delta State should use their power to rig election in Delta State (See Appendix 1).

The implication of this finding is that no matter how powerful any political party is, election should be free and fair in Delta State. Rigging should not be part of election process.

\subsubsection{Research Question 3}

When election malpractice occurs in the society, can this have adverse effects on the moral development of the growing population?

Table 3: Patterns of Distribution of the Effect of Election Malpractice

\begin{tabular}{cccc}
\hline Total Items & Response & Frequency & Percent \\
\hline \multirow{2}{*}{10} & Yes & 408 & 81.6 \\
& No & 92 & 18.4 \\
& Total & 500 & 100 \\
\hline
\end{tabular}

Table 3 shows the pattern of distribution of the effect of election malpractice on the moral development for the growing population. The result revealed that 408 respondents representing 81.6 percent of the total respondents agreed to the fact that election malpractice has adverse effect on the moral development of the growing population. While 92 
respondents representing 18.4 percent of the total respondents is against the fact that election malpractice occurs in the society does not have any effect on the moral development of the growing population (See Appendix 1).

The implication of this finding is that when election malpractice is exhibited during election, this could affect the moral development of the growing youths and population.

\subsubsection{Hypothesis}

There is no significant relationship between election malpractice and examination malpractice that occur in the society

Table 4: Correlation Table

\begin{tabular}{lcc}
\hline Election Malpractice & Election Malpractice & Examination Malpractice \\
Pearson Correlation & 1 & .146 \\
Sig (2-Tailed) & & .001 \\
$N$ & 500 & 500 \\
Examination malpractice & & \\
Pearson Correlation & .146 & 1 \\
Sig (2-Tailed) & .001 & 500 \\
N & 500 &
\end{tabular}

Table 4 shows the SPSS output for the Pearson Correlation of election malpractice and examination malpractice that occur in the society. The result reveals that there is a significant relationship between election malpractice and examination malpractice in schools. The significance value of the correlation represented as $r=.146, N=500$, sig. $=.001$. This shows that Examination malpractice is perfectly correlated with election malpractice.

\section{Discussion}

The research sets out to investigate relationship between election malpractice as a deviant behaviour and examination malpractice in the University. The objective was to find out if this election malpractice can have any relationship with examination malpractice that occurs in the university. The study was to investigate if the settings, in the two situations correlate. The factors the research had in mind were that since the larger society is different from the university community; there may be no relationship between election malpractice and examination malpractice. Three research questions and one hypothesis were stated to guide the study.

From the results, there is evidence that election, malpractice occurs in the society in Delta State. It is the opinion of the respondents that this should not be. The result shows that election malpractice in the outer society can affect the moral development of the growing youths. This relationship between the two variables is capable of doing damage to the character of our younger generation that are being trained in the Universities.

The respondents had the following about the issue of election malpractice and examination malpractice:

1) That the two malpractices are deviant behaviour.

2) The respondents felt bad about this show of deviant behaviour

3) That when young people witness adults practicing election malpractice, their morality can be adversely affected and they will see nothing wrong in practicing examination malpractice, since at their age in the university, their character is still being developed.

4) Electoral malpractice and examination malpractice are deviant behaviours as seen in the definition of Morgan et al., (2008), that behaviour is deviant when it does not conform with the norms of the society. This is also the views of the respondents. Bolin and Heathery (2001) says that deviant behaviour can be destructive. This view is similar with those of the respondents who say that examination and electoral malpractice can have adverse effect on the moral growth of the growing generation.

\section{Implications}

The findings of this study have certain implications for the Nigerian society. Since election malpractice has been seen to 
be capable of affecting the character of the young people; efforts should be made to discourage election and examination malpractice. If election malpractice is not checked, the moral development of our young people will experience decay, and they may grow up seeing nothing wrong in engaging in other deviant behaviours such as theft. If this happens, the society will be worse off.

\section{Recommendations}

From the findings of this study, the following recommendations have been made:

1) Efforts should be made to eliminate election malpractice as a deviant behaviour.

2) Citizenship education should be encouraged in our universities where the ideas of free and fair election will be part of the syllabus.

3) Our news media should be encouraged to mount programmes that discourage election and examination malpractices.

4) Religious organisations, such as churches and Islamic organisations should mount programmes that will encourage free and fair elections and examinations.

\section{References}

Bolin, A. and Heathery, L. (2001).Predictors of employee deviance. The relationship between bad attitude and bad behaviours. Journal of Business Psychology. 15(3): $405-415$.

Borg, S.E. and Gall, R.A. (1989).Educational Research: An Introduction. $8^{\text {th }}$ edition. Longman London.

Browen, R.B. (1999). Emotions and Behaviour. Exercises in Emotional Intelligence. Journal of Management Education, 27(1): 122 134.

Burton, Michel and Lee (2005).Promoting the ethics and integrity of business and technical education. Examination Ethics Project, Lagos, Nigeria.

Chirusha, V. And Mahapa, M. (2012). An Analysis of Causes and Impact of deviant behaviour in the Workplace: The Case of Secretaries in State Universities. Journal of EE and Management, 2, 2141-7029.

Liddel, H.G. and Scott, R. (2008).Peruses Digital Library (Online). Available at http://www.everything.2.com

Mahapa, I. (2010). Co-workers backstabbing strategies, motives and responses. A paper presented at the Annual Meeting of the International Communication. TBA. San Francisco C.A.

Morgan, C.T., King, R.A., Weisz, J.R. and Schopler, J. (2008).Introduction to Psychology. Tata McGraw-Hill Publishing Company Ltd., New Delhi.

Ogba, E. (2004). The many antics of Examination racketeers. Examination Malpractice. An Indepth Analysis. Abuja, Federal Ministry of Education.

Taiwo, J. (2004). Stakeholders panacea for cultism and examination malpractice. Abuja, Federal Ministry of Education: Conference Paper on Examination Malpractice.

Thibant, A. and Kelly, P.C. (1959).Towards developing a theoretical model on the determinants of workplace deviance among support personnel in the Malaysian Public Service Organisations.http://www.googleco.zw. 
